\title{
Enhancement of the Hydrodynamic Characteristics in Shell-and-Tube Heat Exchangers by Using W-Baffle Vortex Generators
}

\author{
Younes Menni1*, Ali J. Chamkha², Houari Ameur³, Mustafa Inc ${ }^{4,5}$ \\ ${ }^{1}$ Unit of Research on Materials and Renewable Energies, Department of Physics, Faculty of Sciences, Abou Bekr Belkaid \\ University, P. O. B. 119, 13000 Tlemcen, Algeria \\ 2 Faculty of Engineering, Kuwait College of Science and Technology, 7th Ring Road, Doha, Kuwait \\ ${ }^{3}$ Department of Technology, University Centre of Naama-Salhi Ahmed, P. O. B. 66, 45000 Naama, Algeria \\ ${ }^{4}$ Department of Mathematics, Faculty of Science, Firat University, 23119 Elazig, Turkey \\ ${ }^{5}$ Department of Medical Research, China Medical University Hospital, China Medical University, 404 Taichung, Xueshi Road $91 .$, \\ Taiwan \\ * Corresponding author, e-mail: menniyounes.cfd@gmail.com
}

Received: 29 December 2019, Accepted: 20 May 2020, Published online: 22 July 2020

\begin{abstract}
Improving the hydrodynamic characteristics of STHECs (Shell-and-Tube Heat Exchanger Channels) by using BVGs (Baffle-type Vortex Generators) is among the common passive methods due to their proved efficiency. In this computational investigation, the same method is used to enhance the hydrodynamic behavior of STHECs, by inserting W-shaped Baffle-type Vortex Generators. The numerical model represented by the computational FVM (Finite Volume Method) is used to simulate and analyzed the considered physical model. The fluid used is air, its thermal physical properties are constant, turbulent, incompressible, and its temperature is $300 \mathrm{~K}$ at the inlet section of the STHEC. The flow velocity $\left(U_{i n}\right)$ and atmospheric pressure $\left(P_{a t m}\right)$ are considered as boundary conditions at the entrance $(x=0)$ and exit $(x=L)$ of the channel, respectively. The results showed that the friction coefficients were related to the pressure, velocity, and Reynolds number values. High values of Re yielded an acceleration of the fluid, resulting thus in increased pressure on the solid walls and augmented friction values.
\end{abstract}

Keywords

hydrodynamic aspect, W-shaped baffle, rectangular channel, turbulent flow, air-fluid, numerical simulation

\section{Introduction}

Several hydrothermal configurations have been proposed and studied by many authors to single out an optimized structure for improving the energy performance of various thermal devices such as the solar heaters and Heat Exchangers. Using numerical and experimental methods, Ary et al. [1] studied the hydrothermal characteristics of inclined and perforated type baffles in a rectangular section channel. They used the SST $k-\omega$ model to model the turbulent fluid field. Using inclined solid and perforated type baffles, Dutta and Hossain [2] experimentally investigated the local characteristics of heat transfer as well as the profiles of skin friction coefficients inside a channel of rectangular form. In this experiment, two baffles with similar overall size were reported to increase the heat transfer. The first baffle is placed on the hot upper wall while the station, orientation, as well as the form of the second baffle, is changed to determine the optimum geometry for improved thermal transport. Using fully/half perforated type baffles, Karwa and Maheshwari [3] experimentally reported the results of thermal transfer and skin friction aspects in a duct with a rectangular section. Using various configurations of transverse and perforated type ribs, Nuntadusit et al. [4] determined the hydrothermal behavior of air inside a horizontal section channel. The impact of the angle of perforation/hole inclination, as well as the station of the hole on the rib, were studied and analyzed experimentally. Using a rectangular type baffle, Gajusingh et al. [5] experimentally conducted a study to examine the flow configuration inside a channel of square section. Using a three-dimensional numerical model, Promvonge et al. [6] 
simulated the laminar heat transfer behavior in a square channel with inclined baffles of different flow blockage ratios. Using perforated and semiattached type ribs, Liu and Wang [7] numerically determined the local thermal transport and fluid field characteristics inside a rectangular type channel. Five various configurations of ribs, as well as two stations, were investigated. Using new continuous rectangular type baffles, Menasria et al. [8] numerically presented the turbulent heat transfer structure for a channel in its rectangular section. The commercial Fluent was used to simulate the turbulent convective transfer of heat, while the RNG $k-\varepsilon$ type model was used to model the turbulent flow. Using different arrangements of fins, Mokhtari et al. [9] reported a three-dimensional simulation to investigate the laminar convective transfer of heat inside a horizontal type channel. Using an inclined baffle type obstacle, Nasiruddin and Siddiqui [10] numerically analyzed the improvement of transfer of heat inside a HE (Heat Exchanger) tube. The used numerical model simulated the impact of the obstacle size as well as its orientation on the hydrothermal enhancement. In this study, three various obstacle arrangements were reported, i.e., vertical, upstream inclined, and downstream inclined. Using inclined and detached type ribs of various values of angle of flow attack, Yongsiri et al. [11] numerically determined the turbulent convective thermal transport inside a channel. A vertical obstacle was also presented for comparison. Ko and Anand [12] experimentally reported a study to determine the average values of thermal transfer coefficients inside a rectangular type channel with a wall placed porous type obstacles. $\mathrm{Li}$ et al. [13] conducted a numerical analysis to investigate the characteristics of flow and heat transfer for a rectangular type channel with staggered and porous type blocks. The velocity field structure as a function of Da (Darcy number), Re (Reynolds number), and porous block structural parameters was analyzed. Guerroudj and Kahalerras [14] numerically used the triangular, trapezoidal, and rectangular-type porous-structure blocks to increase the overall performance of a $2 \mathrm{D}$ channel with parallel plates. Targui and Kahalerras [15] numerically simulated the performance of a double pipe type HE with porous type baffles. Using impermeable and porous type baffles, Santos and de Lemos [16] showed the numerical results of a laminar type flow in a horizontal section channel. Kiwan and Al-Nimr [17] used the porous type fins as a novel method to enhance the transfer of heat from a given surface. The solid conventional fins were also presented for comparison. Using inclined horseshoes baffles,
Promvonge et al. [18] determined the coefficients of heat transfer and friction, as well as the factor of thermal improvement for an experimental tubular HE. Using solid and porous type materials, Ramani et al. [19] theoretically and experimentally studied the thermal and pressure drop characteristics of a double pass SAC (Solar Air Collector). Using the SST method, Deng et al. [20] experimentally investigated the thermal enhancement in a flat-plate type SAC. Saedodin et al. [21] numerically and experimentally used the PMF (Porous-Metal-Foam) to augment the energetic performance of a flat-plate type SC. Using an experimental validation, Hernández and Quiñonez [22] estimated the natural convection heat transfer in SAHCs (Solar-AirHeating-Collectors). Using circular and V-shaped obstacles placed on the absorber, Rajaseenivasan et al. [23] reported an experimental and theoretical analysis of the capacity of a SPSAH (Single-Pass-Solar-Air-Heater). Using numerically triangular wavy type baffles, Eiamsaard and Promvonge [24] enhanced the laminar heat transfer characteristics of a rectangular form channel. Using a CFD software, Jiang et al. [25] showed a simulation on the HEs (Heat Exchangers) with helical type baffles. To investigate the thermal transport and pressure loss behaviors, Tan et al. [26] experimentally used non-Newtonian type nanofluids in the shell-side of a helical type baffle with low-finned-tubes. Wang et al. [27] experimentally evaluated and compared the performance of HEs with COTH (Circumferential-Overlap-Trisection-Helical) type baffles and oil-water type fluids. Using a numerical technique, Galushchak et al. [28] simulated the thermal behavior of a tube with PHT (Punched-Helical-Tape) baffles. Other flow and heat transfer structures can be found in Ghachem et al. [29], Al-Rashed et al. [30, 31], Ghalambaz and Zhang [32], Ghalambaz et al. [33-35], Fodor [36], Mehryan et al. [37, 38], Kolsi [39], Kolsi et al. [40, 41], Rábai and Vad [42], Hajjar et al. [43], Rahimi et al. [44], Rashidi et al. [45], Hegedüs et al. [46], Almeshaal et al. [47], Hnaien et al. [48], Füle and Hernádi [49], Goda and Bánhidi [50], Bidar et al. [51], Noghrehabadi et al. [52-54], Khrabry et al. [55], Fenyvesi and Horváth [56], Zadeh et al. [57], Jamesahar et al. [58], Rashad [59-63], Ismael [64-67], Ismael and Al-Rabeh [68], and Selimefendigil [69-72].

The aim of the study was mainly focused on improving the hydrodynamic characteristics of Shell-and-Tube Heat Exchanger Channels through the technique of planting obstacles on their inner walls. The method is very well known, as mentioned in many previous studies. The various main points that were included in this study are: 
- Control of fluid flow by presenting the streamlines

- Define fast-flow zones by giving axial velocity fields

- Identify low-pressure regions and their relationship to recycling zones

- The relationship of axial velocity to pressure and its effect on the coefficients of friction

- Relation of Reynolds' values to flow characteristics.

\section{$2 \mathrm{~W}$-shaped baffled channel under study}

The channel model studied is shown in Fig. 1. It is a horizontal channel, according to the axial axis, that has a rectangular section, with two obstacles (or vortex generators) of the shape "W". All channel elements, i.e., walls and W-baffles, as well as their dimensions, are shown in Fig. 1. Air is used as a working fluid. This study is complementary to the study mentioned in the referenced paper [73]. Assuming that the airflow is steady, turbulent, Newtonian, incompressible, and then the flow equations can be written as [74]:

- Continuity equation (Eq. (1)):

$$
\frac{\partial u_{j}}{\partial x_{j}}=0 .
$$

- Momentum equation (Eq. (2)):

$$
\rho u_{j} \frac{\partial u_{i}}{\partial x_{j}}=-\frac{\partial P}{\partial x_{i}}+\frac{\partial}{\partial x_{j}}\left(\mu \frac{\partial u_{i}}{\partial x_{j}}-\rho \overline{u_{i}^{\prime} u_{j}^{\prime}}\right) .
$$

The standard $k-\varepsilon$ model [75] was used for modeling the turbulence, for a range of Reynolds number varying from 12,000 to 32,000 . The model relationships for the turbulent-kinetic-energy $(k)$ and its rate $(\varepsilon)$ of dissipation are as follows:

$$
\frac{\partial}{\partial x_{j}}\left(\rho k u_{j}\right)=\frac{\partial}{\partial x_{j}}\left[\left(\mu+\frac{\mu_{t}}{\sigma_{k}}\right) \frac{\partial k}{\partial x_{j}}\right]+G_{k}+\rho \varepsilon
$$

and

$$
\frac{\partial}{\partial x_{j}}\left(\rho \varepsilon u_{j}\right)=\frac{\partial}{\partial x_{j}}\left[\left(\mu+\frac{\mu_{t}}{\sigma_{\varepsilon}}\right) \frac{\partial \varepsilon}{\partial x_{j}}\right]+C_{1 \varepsilon} \frac{\varepsilon}{k}-C_{2 \varepsilon} \rho \frac{\varepsilon^{2}}{k} .
$$

The hydraulic boundary conditions are defined as:

- At the intake, $(x=0,-H / 2 \leq y \leq H / 2)$ :

$$
\begin{aligned}
& u=U_{i n} \\
& v=0 \\
& k_{i n}=0.005 U_{i n}^{2} \\
& \varepsilon_{i n}=0.1 k_{i n}^{2}
\end{aligned}
$$

- At the outlet, $x=L$ :

$P=P_{a t m}$

$\partial u / \partial x=\partial v / \partial x=\partial k / \partial x=\partial \varepsilon / \partial x=0$

- At the solid walls, $y=H / 2$ and $y=-H / 2$ :

$u=v=0$

$k=\varepsilon=0$

- Reynolds number, Re

$$
\operatorname{Re}=\rho \bar{U} D_{h} / \mu
$$

- The hydraulic diameter of the channel, $D_{h}$

$$
D_{h}=2 H W /(H+W)
$$

- Skin friction coefficient, $C f$

$$
C_{f}=2 \tau_{w} / \rho \bar{U}^{2}
$$

- Friction factor, $f$

$$
f=2(\Delta P / L) D_{h} / \rho \bar{U}^{2} .
$$

\section{Numerical methods}

The simulation adopts the computational method of finite volumes [76] to give the numerical solution, using the Commercial CFD ANSYS Fluent 12.0 [77]. To discretize the computational domain, a structured mesh

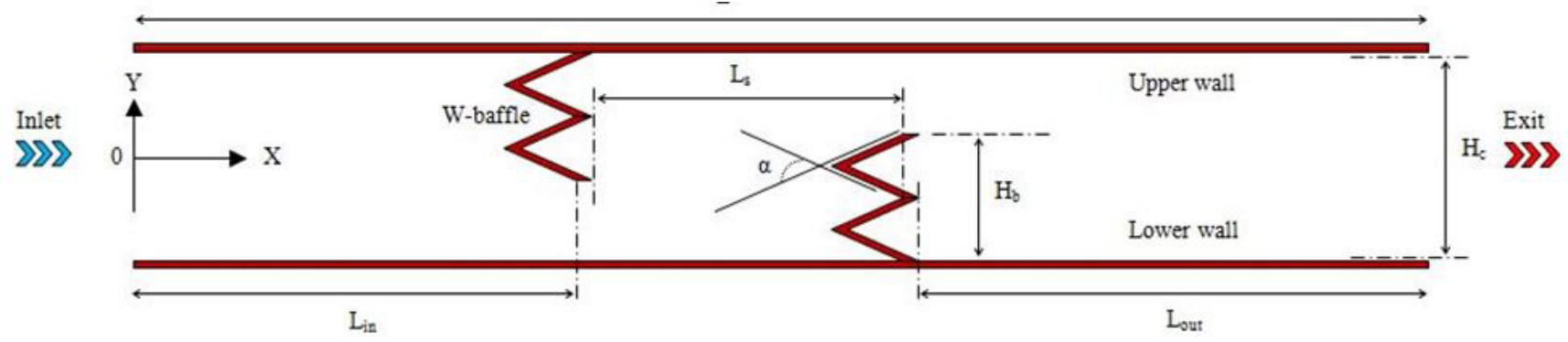

Fig. 1 Computational domain under simulation $\left(L=0.554 \mathrm{~m}, L_{\text {in }}=0.218 \mathrm{~m}, L_{s}=0.142 \mathrm{~m}, L_{\text {out }}=0.174 \mathrm{~m}, H_{b}=0.08 \mathrm{~m}, H_{c}=0.146 \mathrm{~m}, \alpha=45^{\circ}\right.$, and $\left.D_{h}=0.167 \mathrm{~m}\right)$. 
of quadrilateral type cells is used, see Fig. 2. To model the hydrodynamic behavior of the fluid flow, a non-uniform mesh of $(245 \times 95)$ nodes was chosen, according to the $X$ and $Y$ axes, respectively. To obtain high-velocity gradients, the mesh was enhanced near the solid boundaries, by increasing the cell density. Some grid sizes were examined to ensure the accuracy of the numerical solution value and its independence from the mesh node density. These mesh systems are as follows, $(95 \times 35),(120 \times 45)$, $(145 \times 55),(170 \times 65),(195 \times 75),(220 \times 85),(245 \times 95)$ and $(370 \times 145)$ nodes, in $X$ and $Y$ directions, respectively.

The mean friction coefficient $(f)$ were tested on the entire upper horizontal line $(0 \leq x \leq L, y=H / 2)$ of the channel. The grid system with $(245 \times 95)$ cells resulted in a $0.392 \%$ deviation, compared to that provided by the $(370 \times 145)$ cell grid. For this, the system composed of $(245 \times 95)$ cells was previously used.

In the first part of this research work, which contains the "heat transfer aspect", previously published (see [73]), we compared our dimensionless axial velocity $\left(u / U_{i n}\right)$ curves with the numerical ones from Demartini et al. [74], to validate the present numerical model used, see Fig. 3.

In the second part of our research work, which includes the "hydrodynamic features", a comparison of the predicted pressure coefficients against the experimental data

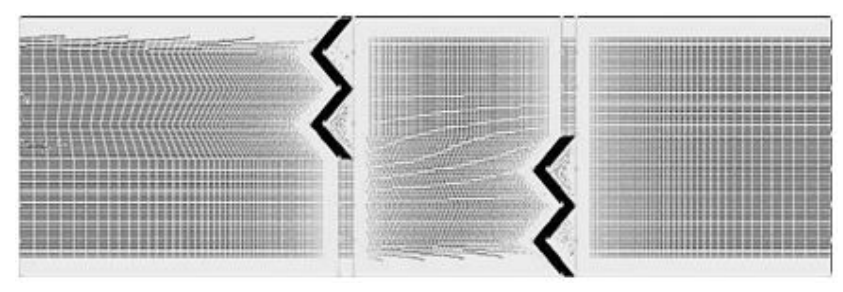

Fig. 2 Mesh used for the computational domain.

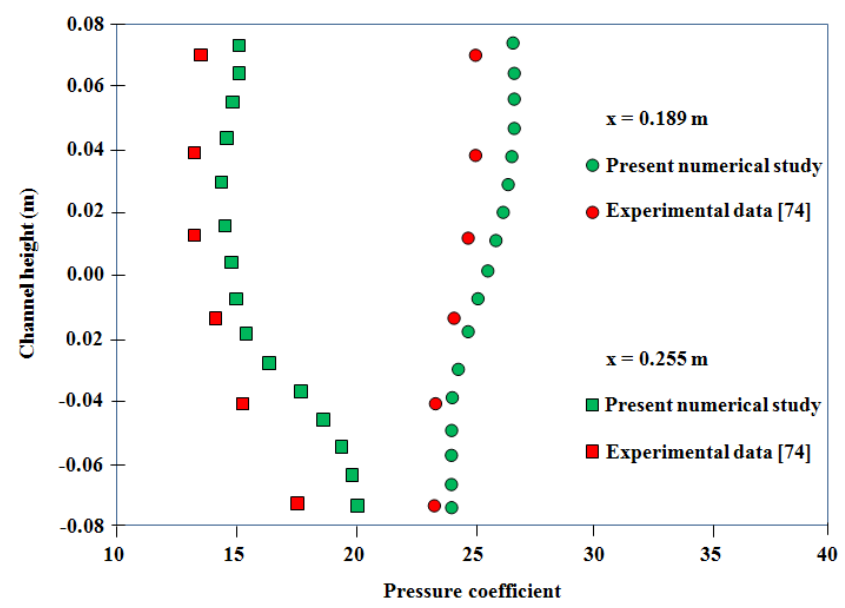

Fig. 3 Numerical validation with the referenced paper [74], under the same geometry and flow conditions: rectangular channel with baffle plates, air-fluid, turbulent flow, and $\operatorname{Re}=8.73 \times 10^{4}$ (or $U_{\text {in }}=7.8 \mathrm{~m} / \mathrm{s}$ ). of Demartini et al. [74] was made. The comparison was carried out under the same flow and geometry conditions, used by Demartini et al. [74]. After proving the validity of our numerical model, we used this validated numerical model for the present new channel with W-shaped baffles for simulation.

\section{Results and discussion}

\subsection{Streamlines and axial velocity contours}

To display the hydraulic characteristics included in this study, the flow fields are shown in terms of streamlines and axial velocity contours, as reported in Figs. 4 and 5, respectively.

The effect of each of the WBs, i.e., W-shaped baffles, and the number of Reynolds, from 12,000 to 32,000, are also

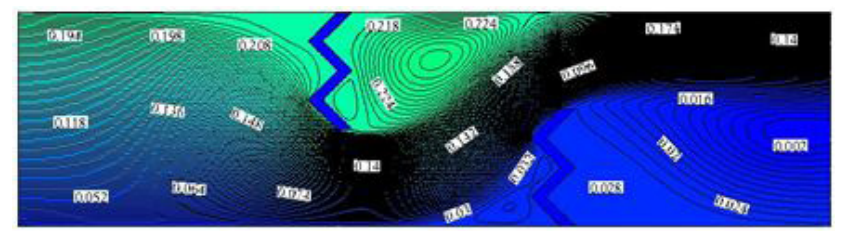

(a)

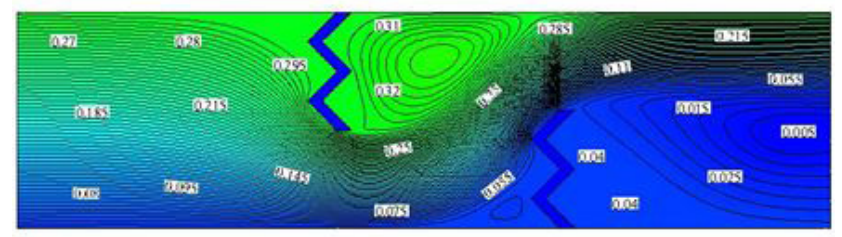

(b)

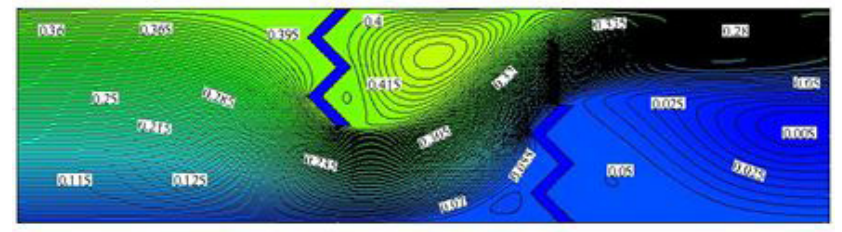

(c)

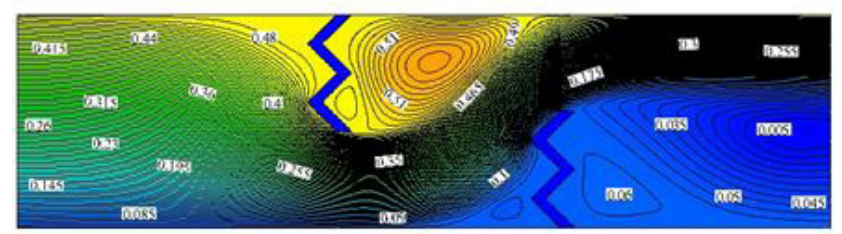

(d)

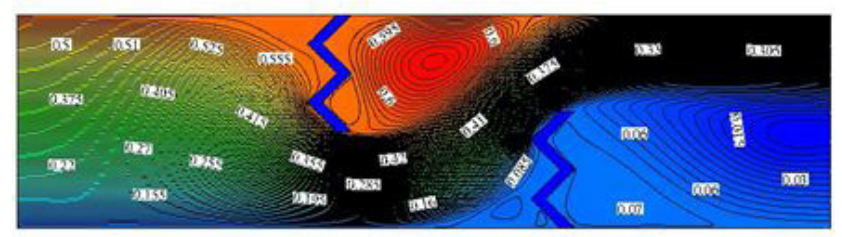

(e)

$\begin{array}{lllllllllllll}\text { stream-function: } & 0.05 & 0.1 & 0.15 & 0.2 & 0.25 & 0.3 & 0.35 & 0.4 & 0.45 & 0.5 & 0.55 & 0.6\end{array}$

Fig. 4 Streamlines for (a) $\operatorname{Re}=12,000$, (b) $\operatorname{Re}=17,000$, (c) $\operatorname{Re}=22,000$, (d) $\operatorname{Re}=27,000$, and (e) $\operatorname{Re}=32,000$. 


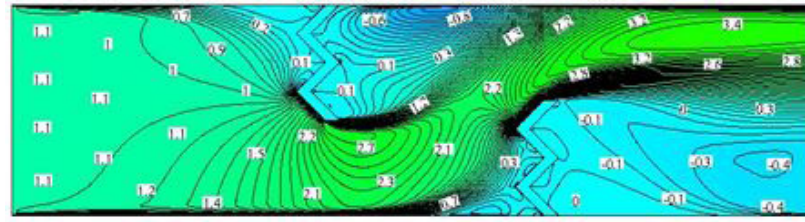

(a)

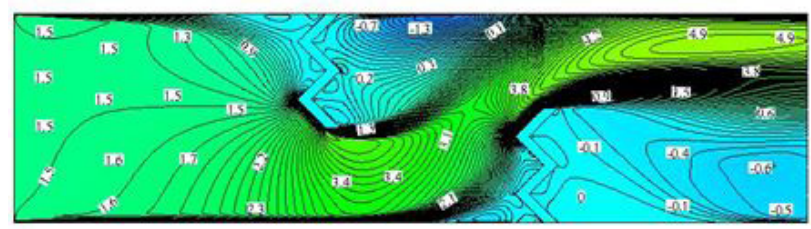

(b)

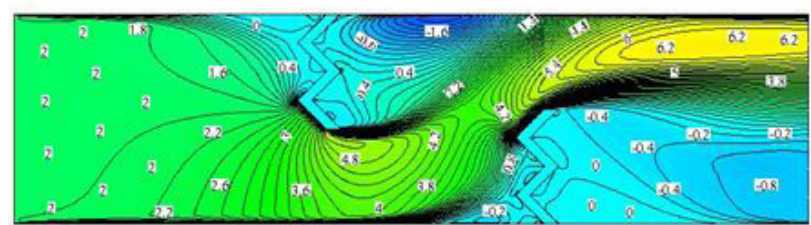

(c)

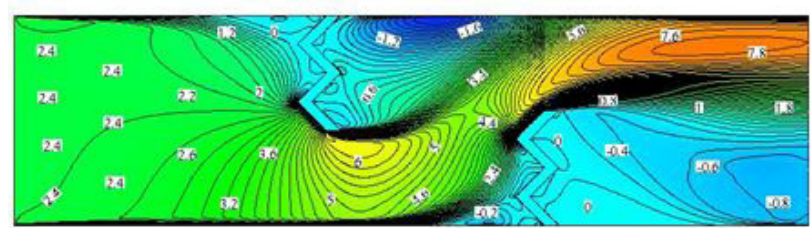

(d)

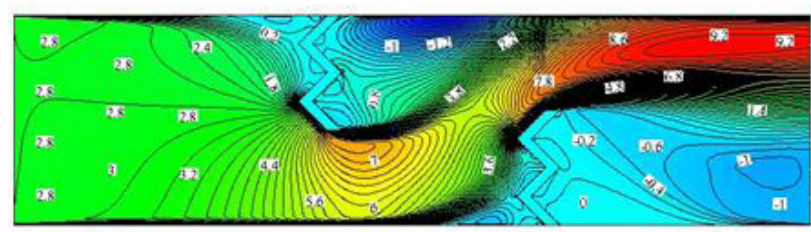

(e)

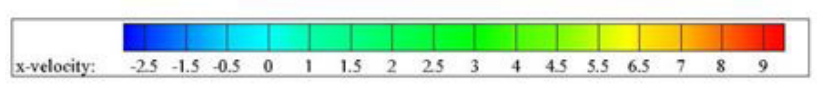

Fig. 5 Axial velocity fields for (a) $\operatorname{Re}=12,000$, (b) $\operatorname{Re}=17,000$, (c) $\operatorname{Re}=22,000$, (d) $\operatorname{Re}=27,000$, and (e) $\operatorname{Re}=32,000$.

shown. The angle of flow attack, from the WBs, was fixed at $45^{\circ}$, during the simulation. The flow field, in the presence of WBs, can be visualized by using these fluid contours.

The flow field of air clearly shows a decrease in axial velocity values, near the surfaces of the WBs, especially in areas near the rear sides. This is due to the concentration of a large ring of recycling cells in the region.

On the other hand, there is an increase of the axial velocity in the areas located near the top edges of the WBs, which extend to the channels wall surfaces. This increase is due to the presence of WBs, as a first cofactor. While, the second factor is the results of the presence of recycling cells on the right side of the WBs. These two factors cause a sudden change in the flow direction.
Moreover, maximum axial velocity values are present in the last section of the channel, and precisely, in the vicinity of its upper wall, to the right of the lower WB. This behavior from the flow field is due to the presence of the WBs.

The analysis of the flow field also showed that the axial values of velocity are affected by the change in Reynolds number, as there is a direct correlation between them.

\subsection{Axial velocity profiles}

The axial velocity profiles are also presented in the study, for a good detail in analyzing the results.

The $x$-speed curves are shown in the first section of the channel, exactly at the axial locations $x=0.159 \mathrm{~m}$ and $x=0.179 \mathrm{~m}$, from the inlet (at $x=0$ ), i.e., $0.059 \mathrm{~m}$ and $0.039 \mathrm{~m}$ before the left side of the upper WB. Fig. 6 (a) lists these profiles for $\mathrm{Re}=12,000$.

The axial velocity profiles reveal a decrease in axial velocity values on the front side of this obstacle, due to the approaching flow from the left side of the same obstacle. As expected on the lower region of the channel, the fluid flows and accelerates towards the bottom area of the obstacle.

The axial velocity profiles are also shown in the second part of the channel, away from the right side of the top WB with distances of $0.027 \mathrm{~m}$ and $0.057 \mathrm{~m}$, i.e., $0.255 \mathrm{~m}$ and $0.285 \mathrm{~m}$; and $0.299 \mathrm{~m}$ and $0.269 \mathrm{~m}$ from the inlet and outlet sections, respectively (Fig. 6 (b)).

These profiles show high values of axial velocity at the bottom section of the channel, approximately $2.689 \mathrm{~m} / \mathrm{s}$, i.e., 2.562 times (or $256.222 \%$ ) the entrance speed. As expected in the upper section, these negative values indicate and confirm the presence of recycling cells in the region.

In the same region, i.e., the second part of the channel, behind the upper WB and front of the lower WB, in the adjacent positions $x=0.315 \mathrm{~m}$ and $x=0.335 \mathrm{~m}$ from the entrance, i.e., $0.239 \mathrm{~m}$ and $0.219 \mathrm{~m}$ from the exit, more than that, $0.087 \mathrm{~m}$ and $0.107 \mathrm{~m}$; and $0.055 \mathrm{~m}$ and $0.035 \mathrm{~m}$ after and before the two WBs, respectively, the axial velocity profiles are shown, as reported in Fig. 6 (c).

The velocity of the fluid shows down next to the left side of the bottom WB, while there is an acceleration of the flow towards the top gap, on its top surface. The negative values of velocity, positioned at the bottom of the profiles, for the position closest to the second WB, i.e., $x=0.335 \mathrm{~m}$, are evidence of the presence of a tiny recycling zone on its left side. 


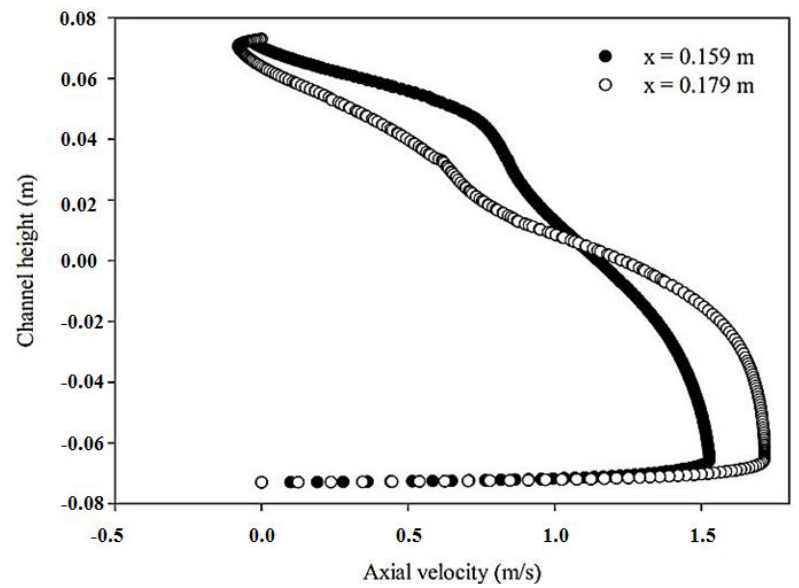

(a)

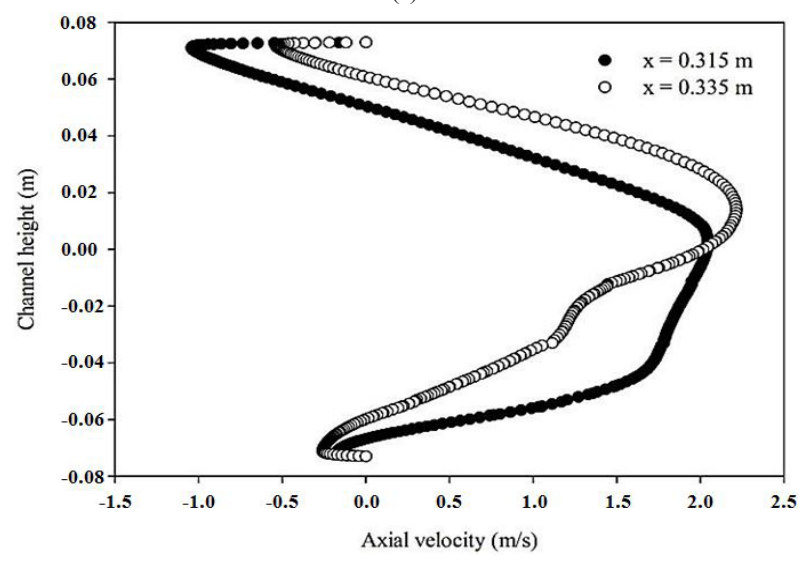

(c)

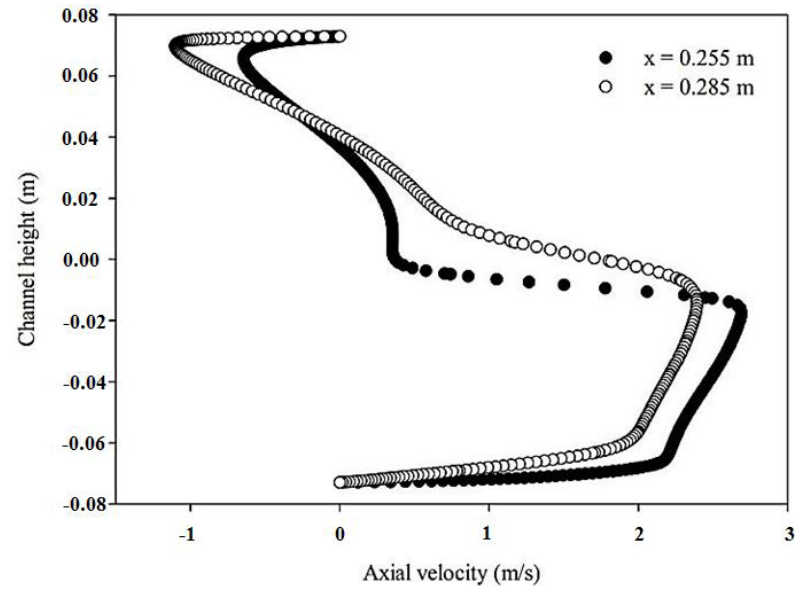

(b)

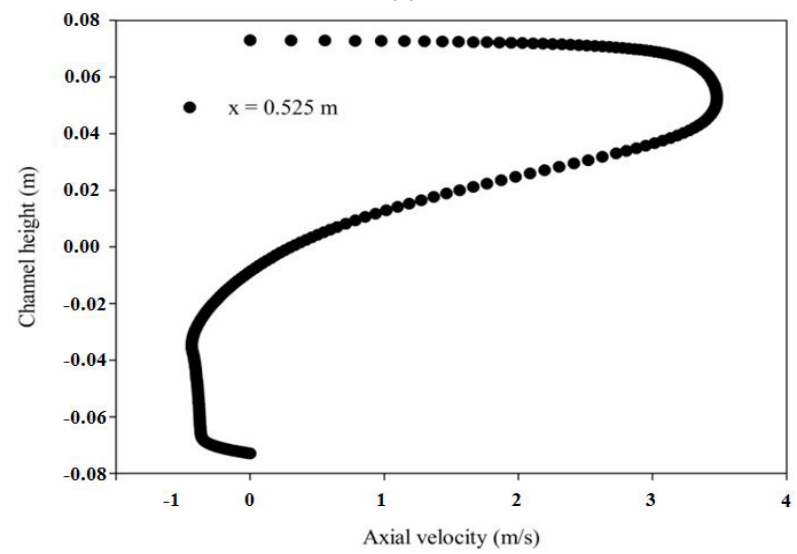

(d)

Fig. 6 Profiles of axial velocity at (a) $x=0.159 \mathrm{~m}$ and $x=0.179 \mathrm{~m}$, (b) $x=0.255 \mathrm{~m}$ and $x=0.285 \mathrm{~m}$, (c) $x=0.315 \mathrm{~m}$ and $x=0.335 \mathrm{~m}$, and (d) $x=0.525 \mathrm{~m}, \mathrm{Re}=12,000$.

While, the negative velocities, found in the upper part of the channel, are evidence of the extension of the rotating ring found behind the first $\mathrm{WB}$, to the region.

In the third section of the channel, precisely at $0.029 \mathrm{~m}$ before the exit section $(x=L)$, i.e., $0.145 \mathrm{~m}$ to the right of the bottom WB, i.e., in the position $x=0.525 \mathrm{~m}$, the speed values are maximal as they are 3.314 times the speed of the inlet. This is due to the reduced flow area that is resulted by the presence of WBs, as well as the presence of powerful cells for recycling on their rear sides, Fig. 6 (d).

\subsection{Axial velocity as a function of Reynolds number}

It is obvious that the axial velocity is proportional to variations of the Reynolds number values in the various previously examined regions, as reported in Fig. 7 (a) to 7 (d), for different positions, such as $x=0.179 \mathrm{~m}, 0.255 \mathrm{~m}$, $0.335 \mathrm{~m}$, and $0.525 \mathrm{~m}$, respectively.

The fluid flows from the left to right, according to a direct path, with positive axial velocities. Also, the presence of the WBs creates reverse flows, the axial velocity of which is negative. Both speeds improve as Reynolds' number improves.

\subsection{Skin friction coefficient}

In addition to the axial profiles, there are also normalized skin friction coefficient profiles $\left(C f / f_{0}\right)$, as shown in Fig. 8, for both the top and bottom walls of the channel, with $\operatorname{Re}=12,000$.

On the upper axis, there are low values of $C f / f_{0}$ in the first section of the channel, due to the first WB that affects the flow by directing it towards the lower side, i.e., across the lower gap. In the second section, there are average values of friction due to the presence of a recycling cell in the region, i.e., on the left side of the upper WB.

While, there are maximum values of friction, found in the third section, in the zone located next to the top edge of the second $\mathrm{WB}$, as a result of the change in the direction of the flow deviation. Also, the recycling cell, positioned 


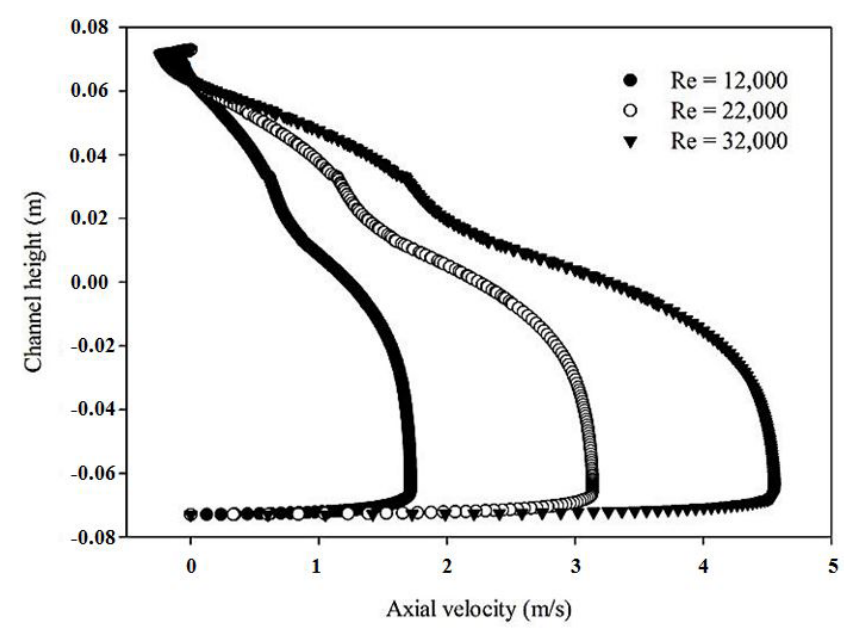

(a)

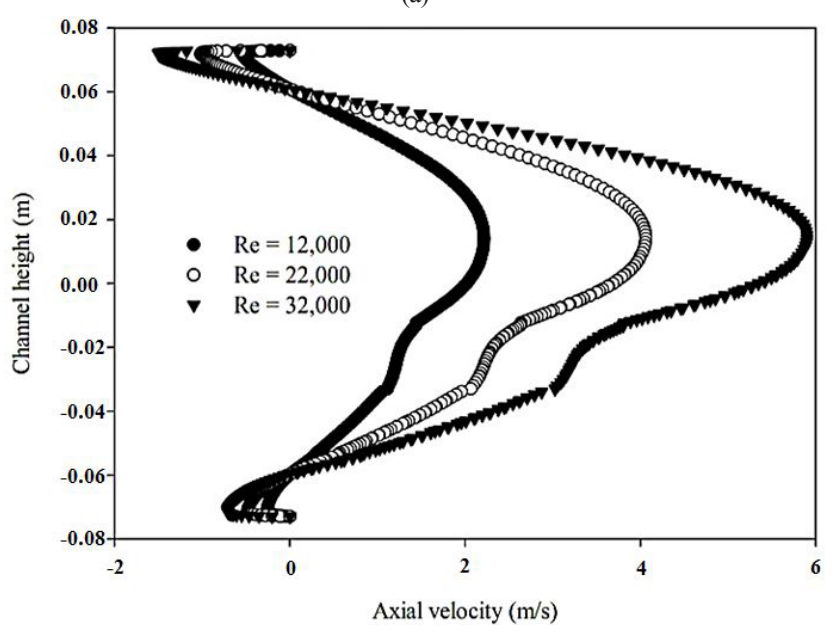

(c)

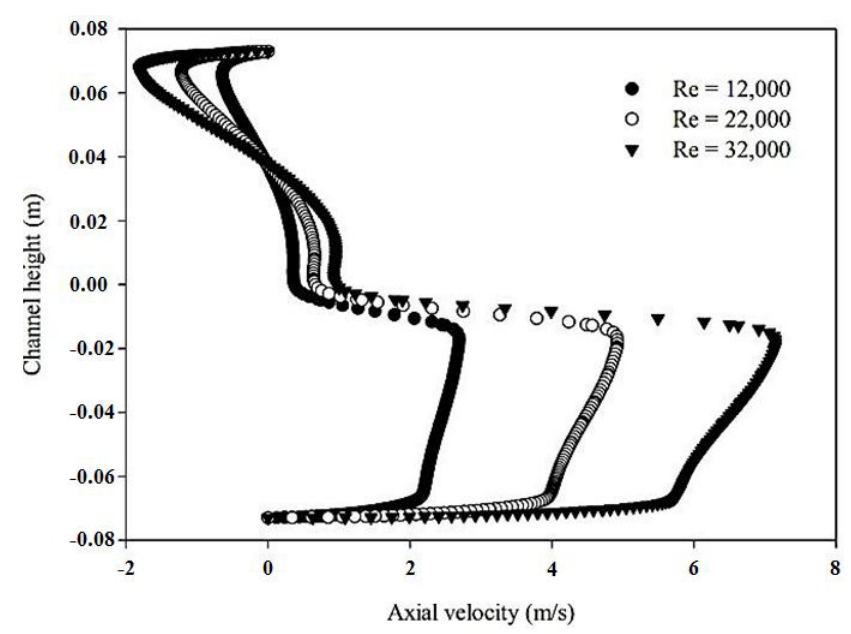

(b)

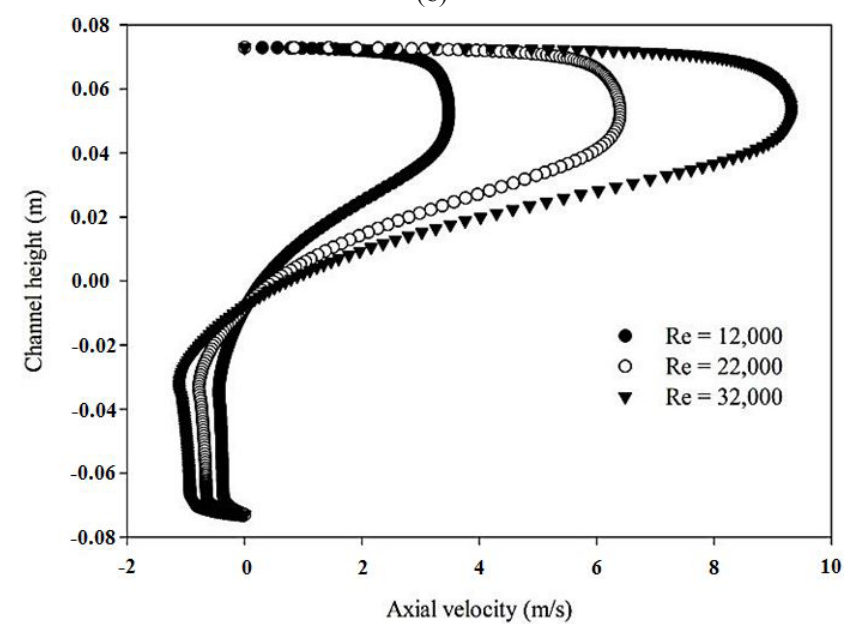

(d)

Fig. 7 Variation of axial velocity profiles with Reynolds number at (a) $x=0.179 \mathrm{~m}$, (b) $x=0.255 \mathrm{~m}$, (c) $x=0.335 \mathrm{~m}$, and (d) $x=0.525 \mathrm{~m}$.

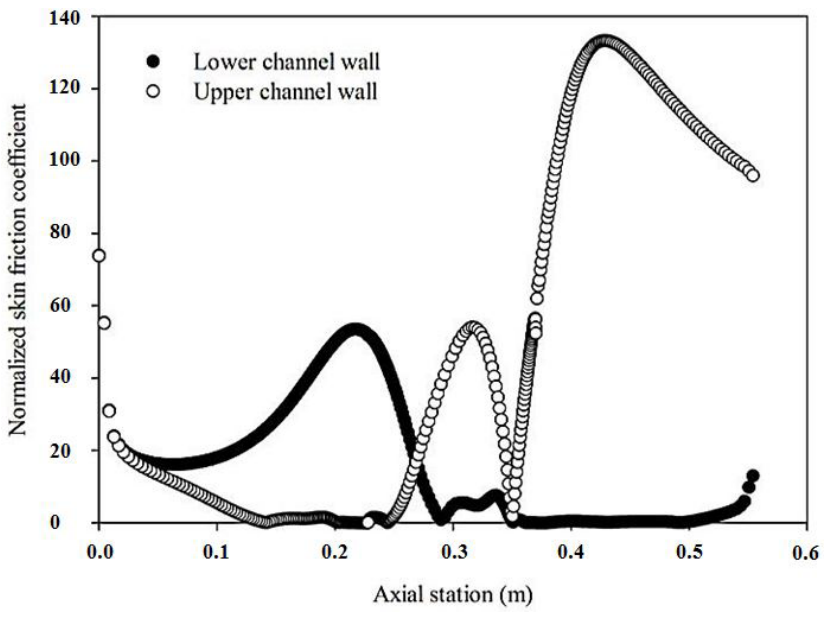

Fig. 8 Distribution of normalized skin friction coefficient, $\mathrm{Re}=12,000$.

behind the bottom WB, at the lower part of the channel, makes it possible to push the direct current upwards.

On the lower wall of the channel, as evidenced by the friction curves, there are very high values near the top face of the top WB, i.e., within the gap boundaries, while they are neglected next to the bottom WB, on both the front and back sides.

\subsection{Skin friction coefficient as a function of Re number}

Effects of Reynolds number on the friction can also be studied as shown in Fig. 9 (a) and (b), for both the upper and lower walls, respectively. Reynolds' values are within the specified range, between 12,000 and 32,000.

As we saw earlier in terms of changing velocity values and their relationship to Reynolds values, it is evident that the value of the friction coefficient is affected when the Reynolds number changes. This can be explained by the fact that the increase in the value of Reynolds number increases the flow disturbance, which increases the dynamic pressure values across the narrow passages, i.e., the gaps, and consequently increases the flow velocity and improves the size of the recycling cells, which induce to raise the values of the coefficients of friction, especially across the gaps. 


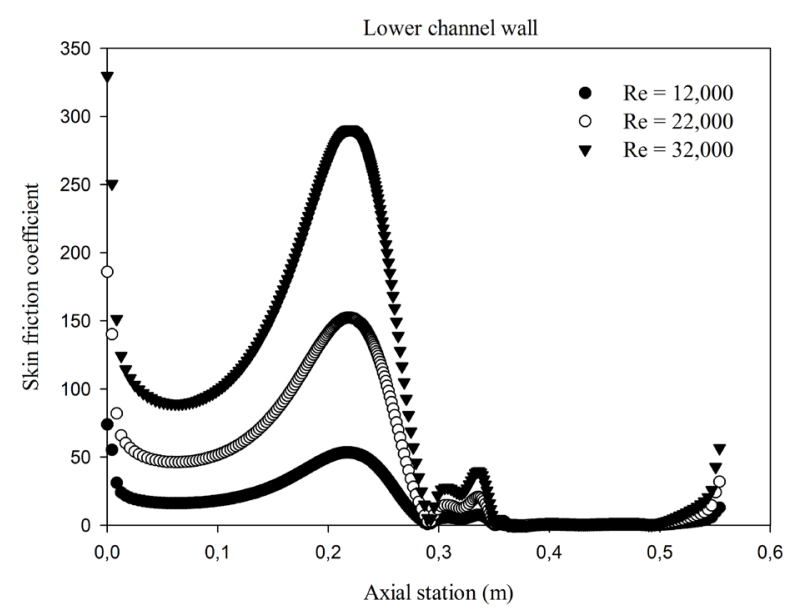

(a)

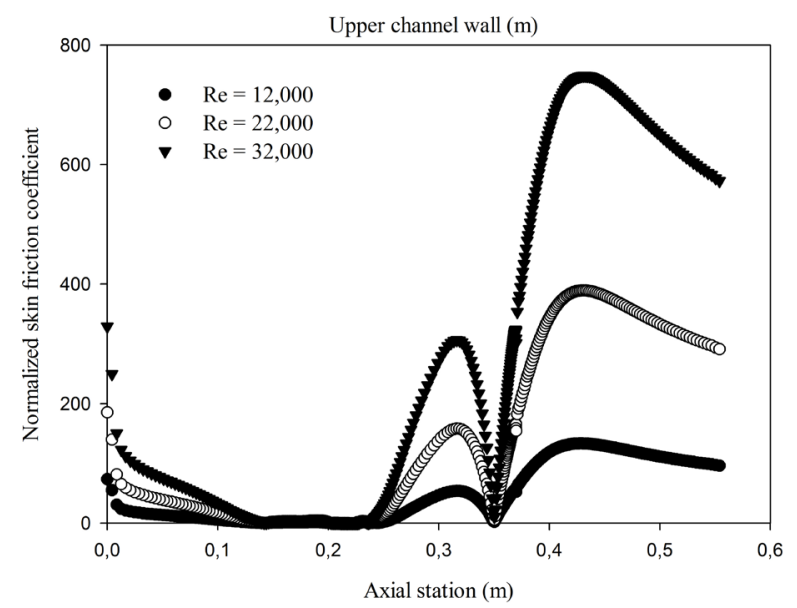

(b)

Fig. 9 Normalized friction coefficients for (a) bottom and (b) top walls of the channel, for different Re values.

\subsection{Friction factor as a function of Reynolds number}

The factor of friction is also discussed in this study by using the Eq. (16). Fig. 10 gives different values for this parameter due to the different Re number values used.

By comparing all the states presented in Fig. 10, we conclude the factor of friction is an increasing function of the Re variable. This confirms the data in the previous Fig. 9.

\section{Conclusion}

In addition to the given heat transfer characteristics [73], we list some of the hydrodynamic features obtained through this study:

- The air flows from the left to right, according to a direct path, with positive axial velocities. Also, the presence of the WBs creates reverse flows, the axial velocity of which is negative.

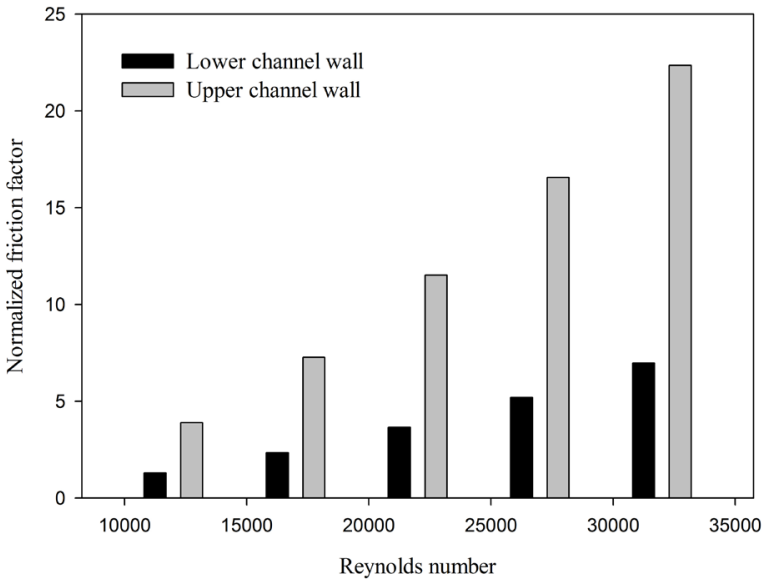

Fig. 10 Variation of normalized friction factor with Reynolds number.

- A decrease in axial velocity values is observed near the surfaces of the WBs, especially in areas near the rear sides, due to the concentration of a large ring of recycling cells in the region.

- There is an increase in axial velocity values, with a sudden change in the flow direction, in the areas located near the top edges of the WBs, which extend to the channels wall surfaces due to the presence of obstacles and recycling cells on their right sides.

- There are maximum axial velocity values in the last section of the channel, and precisely, in the vicinity of its upper wall, to the right of the lower WB.

- The axial values of velocity are affected by the change in Reynolds number, as there is a direct correlation between them.

- There are very high values of skin friction coefficient near the top face of WBs, i.e., within the gap boundaries.

- Factor of friction is an increasing function of the Re variable.

- The friction values are high on the upper wall, if we compare them with those on the lower wall, due to the large velocity values across the upper gap, compared to those found in the lower gap.

The following studies are suggested to complement this research work:

- Using the perforated model for WBs in order to reduce the friction loss in the channel,

- Using the inclined model for WBs in order to decrease the pressure drop in the channel. 


\begin{tabular}{|c|c|c|}
\hline \multicolumn{2}{|c|}{ Nomenclature } & \multirow[b]{2}{*}{ skin friction coefficient } \\
\hline$C f$ & {$[-]$} & \\
\hline$C_{1 \varepsilon}$ & {$[-]$} & turbulent constant \\
\hline$C_{2 \varepsilon}$ & {$[-]$} & turbulent constant \\
\hline$\sigma_{k}$ & {$[-]$} & $k$ - $\varepsilon$ turbulence model constant for $k$ \\
\hline$\sigma_{\varepsilon}$ & {$[-]$} & $k-\varepsilon$ turbulence model constant for $\varepsilon$ \\
\hline$D_{h}$ & {$[\mathrm{~m}]$} & hydraulic diameter of the channel \\
\hline$f$ & {$[-]$} & friction factor \\
\hline$H_{b}$ & {$[\mathrm{~m}]$} & w-baffle height \\
\hline$H_{c}$ & {$[\mathrm{~m}]$} & channel height \\
\hline$k$ & {$\left[\mathrm{~m}^{2} / \mathrm{s}^{2}\right]$} & turbulent kinetic energy \\
\hline$L$ & {$[\mathrm{~m}]$} & channel length \\
\hline$L_{i n}$ & {$[\mathrm{~m}]$} & inlet-first baffle distance \\
\hline$L_{\text {out }}$ & {$[\mathrm{m}]$} & second baffle-exit distance \\
\hline$L_{s}$ & {$[\mathrm{~m}]$} & baffle separation distance \\
\hline$P$ & {$[\mathrm{~Pa}]$} & pressure \\
\hline$P_{a t m}$ & {$[\mathrm{~Pa}]$} & atmospheric pressure. \\
\hline $\operatorname{Re}$ & {$[-]$} & Reynolds number \\
\hline$T$ & {$[\mathrm{~K}]$} & temperature \\
\hline$u$ & {$[\mathrm{~m} / \mathrm{s}]$} & $x$-velocity \\
\hline$u_{i}$ & {$[\mathrm{~m} / \mathrm{s}]$} & velocity in $x_{i}$-direction \\
\hline$U_{i n}$ & {$[\mathrm{~m} / \mathrm{s}]$} & inlet fluid velocity \\
\hline$u_{j}$ & {$[\mathrm{~m} / \mathrm{s}]$} & velocity in $x_{j}$-direction \\
\hline$v$ & {$[\mathrm{~m} / \mathrm{s}]$} & $y$-velocity \\
\hline
\end{tabular}

\section{References}

[1] Ary, B. K. P., Lee, M. S., Ahn, S. W., Lee, D. H. "The effect of the inclined perforated baffle on heat transfer and flow patterns in the channel", International Communications in Heat and Mass Transfer, 39(10), pp. 1578-1583, 2012.

https://doi.org/10.1016/j.icheatmasstransfer.2012.10.010

[2] Dutta, P., Hossain, A. "Internal cooling augmentation in rectangular channel using two inclined baffles", International Journal of Heat and Fluid Flow, 26(2), pp. 223-232, 2005. https://doi.org/10.1016/j.ijheatfluidflow.2004.08.001

[3] Karwa, R., Maheshwari, B. K. "Heat transfer and friction in an asymmetrically heated rectangular duct with half and fully perforated baffles at different pitches", International Communications in Heat and Mass Transfer, 36(3), pp. 264-268, 2009. https://doi.org/10.1016/j.icheatmasstransfer.2008.11.005

[4] Nuntadusit, C., Wae-hayee, M., Bunyajitradulya, A., Eiamsa-ard, S. "Thermal visualization on surface with transverse perforated ribs", International Communications in Heat and Mass Transfer, 39(5), pp. 634-639, 2012. https://doi.org/10.1016/j.icheatmasstransfer.2012.03.001

[5] Gajusingh, S. T., Shaikh, N., Siddiqui, K. "Influence of a rectangular baffle on the downstream flow structure", Experimental Thermal and Fluid Science, 34(5), pp. 590-602, 2010. https://doi.org/10.1016/j.expthermflusci.2009.11.011

$$
\begin{array}{lll}
W & {[\mathrm{~m}]} & \text { channel width } \\
x, y & {[\mathrm{~m}]} & \text { Cartesian coordinates }
\end{array}
$$

\section{Greek symbols}

$\begin{array}{lll}\alpha & {\left[{ }^{\circ}\right]} & \text { attack angle of W-shaped baffle } \\ \rho & {\left[\mathrm{kg} / \mathrm{m}^{3}\right]} & \text { fluid density } \\ \varepsilon & {\left[\mathrm{m}^{2} / \mathrm{s}^{3}\right]} & \text { turbulent dissipation rate } \\ \mu & {[\mathrm{kg} / \mathrm{m} \mathrm{s}]} & \text { dynamic viscosity } \\ \mu_{t} & {[\mathrm{~kg} / \mathrm{m} \mathrm{s}]} & \text { turbulent viscosity } \\ \Delta P & {[\mathrm{~Pa}]} & \text { pressure drop } \\ \tau_{w} & {[\mathrm{~Pa}]} & \text { wall shear stress }\end{array}$

\section{Subscripts}

$\begin{array}{ll}\text { atm } & \text { atmospheric } \\ b & \text { baffle } \\ c & \text { channel } \\ h & \text { hydraulic } \\ \text { in } & \text { inlet } \\ \text { out } & \text { outlet } \\ s & \text { separation } \\ t & \text { turbulent }\end{array}$

[6] Promvonge, P., Sripattanapipat, S., Tamna, S., Kwankaomeng, S., Thianpong, C. "Numerical investigation of laminar heat transfer in a square channel with $45^{\circ}$ inclined baffles", International Communications in Heat and Mass Transfer, 37(2), pp. 170-177, 2010. https://doi.org/10.1016/j.icheatmasstransfer.2009.09.010

[7] Liu, H., Wang, J. "Numerical investigation on synthetical performances of fluid flow and heat transfer of semiattached rib-channels", International Journal of Heat and Mass Transfer, 54(1-3), pp. 575-583, 2011.

https://doi.org/10.1016/j.ijheatmasstransfer.2010.09.013

[8] Menasria, F., Zedairia, M., Moummi, A. "Numerical study of thermohydraulic performance of solar air heater duct equipped with novel continuous rectangular baffles with high aspect ratio", Energy, 133, pp. 593-608, 2017.

https://doi.org/10.1016/j.energy.2017.05.002

[9] Mokhtari, M., Gerdroodbary, M. B., Yeganeh, R., Fallah, K. "Numerical study of mixed convection heat transfer of various fin arrangements in a horizontal channel", Engineering Science and Technology, an International Journal, 20(3), pp. 1106-1114, 2017. https://doi.org/10.1016/j.jestch.2016.12.007

[10] Nasiruddin, M., Siddiqui, M. H. K. "Heat transfer augmentation in a heat exchanger tube using a baffle", International Journal of Heat and Fluid Flow, 28(2), pp. 318-328, 2007. https://doi.org/10.1016/j.ijheatfluidflow.2006.03.020 
[11] Yongsiri, K., Eiamsa-ard, P., Wongcharee, K., Eiamsa-ard, S. "Augmented heat transfer in a turbulent channel flow with inclined detached-ribs", Case Studies in Thermal Engineering, 3, pp. 1-10, 2014.

https://doi.org/10.1016/j.csite.2013.12.003

[12] Ko, K. H., Anand, N. K. "Use of porous baffles to enhance heat transfer in a rectangular channel", International Journal of Heat and Mass Transfer, 46(22), pp. 4191-4199, 2003. https://doi.org/10.1016/S0017-9310(03)00251-5

[13] Li, H. Y., Leong, K. C., Jin, L. W., Chai, J. C. "Analysis of fluid flow and heat transfer in a channel with staggered porous blocks", International Journal of Thermal Sciences, 49(6), pp. $950-962,2010$. https://doi.org/10.1016/j.ijthermalsci.2010.01.006

[14] Guerroudj, N., Kahalerras, H. "Mixed convection in a channel provided with heated porous blocks of various shapes", Energy Conversion and Management, 51(3), pp. 505-517, 2010. https://doi.org/10.1016/j.enconman.2009.10.015

[15] Targui, N., Kahalerras, H. "Analysis of a double pipe heat exchanger performance by use of porous baffles and pulsating flow", Energy Conversion and Management, 76, pp. 43-54, 2013. https://doi.org/10.1016/j.enconman.2013.07.022

[16] Santos, N. B., de Lemos, M. J. S. "Flow and Heat Transfer in a Parallel-Plate Channel with Porous and Solid Baffles", Numerical Heat Transfer, Part A: Applications, 49(5), pp. 471-494, 2006. https://doi.org/10.1080/10407780500325001

[17] Kiwan, S., Al-Nimr, M. A. "Using Porous Fins for Heat Transfer Enhancement", Journal of Heat Transfer, 123(4), pp. 790-795, 2001. https://doi.org/10.1115/1.1371922

[18] Promvonge, P., Tamna, S., Pimsarn, M., Thianpong, C. "Thermal characterization in a circular tube fitted with inclined horseshoe baffles", Applied Thermal Engineering, 75, pp. 1147-1155, 2015. https://doi.org/10.1016/j.applthermaleng.2014.10.045

[19] Ramani, B. M., Gupta, A., Kumar, R. "Performance of a double pass solar air collector", Solar Energy, 84(11), pp. 1929-1937, 2010. https://doi.org/10.1016/j.solener.2010.07.007

[20] Deng, J., Yang, X., Yang, M., Wang, Z. "Experimental Study of a Single-pass Flat Plate Solar air Collector with Severe Dust Deposition on the Transparent Glass Cover", Energy Procedia, 70, pp. 32-40, 2015.

https://doi.org/10.1016/j.egypro.2015.02.094

[21] Saedodin, S., Zamzamian, S. A. H., Nimvari, M. E., Wongwises, S., Jouybari, H. J. "Performance evaluation of a flat-plate solar collector filled with porous metal foam: Experimental and numerical analysis", Energy Conversion and Management, 153, pp. 278-287, 2017.

https://doi.org/10.1016/j.enconman.2017.09.072

[22] Hernández, A. L., Quiñonez, J. E. "Experimental validation of an analytical model for performance estimation of natural convection solar air heating collectors", Renewable Energy, 117, pp. 202-216, 2018. https://doi.org/10.1016/j.renene.2017.09.082

[23] Rajaseenivasan, T., Srinivasan, S., Srithar, K. "Comprehensive study on solar air heater with circular and V-type turbulators attached on absorber plate", Energy, 88, pp. 863-873, 2015. https://doi.org/10.1016/j.energy.2015.07.020
[24] Eiamsa-ard, S., Promvonge, P. "Laminar periodic flow and heat transfer in a rectangular channel with triangular wavy baffles", Journal of Thermal Science, 21(3), pp. 250-261, 2012. https://doi.org/10.1007/s11630-012-0542-5

[25] Jiang, B., Yan, Sh., Zhang, L., Xiao, X. "Numerical research of stream analysis on helical baffles heat exchangers", Journal of Engineering Thermophysics, 26(2), pp. 272-290, 2017. https://doi.org/10.1134/S1810232817020102

[26] Tan, Y., He, Z., Xu, T., Fang, X., Gao, X., Zhang, Z. "Experimental investigation of heat transfer and pressure drop characteristics of non-Newtonian nanofluids flowing in the shell-side of a helical baffle heat exchanger with low-finned tubes", Heat and Mass Transfer, 53(9), pp. 2813-2827, 2017. https://doi.org/10.1007/s00231-017-2015-6

[27] Wang, W., Cheng, D., Liu, T., Liu, Y. "Performance comparison for oil-water heat transfer of circumferential overlap trisection helical baffle heat exchanger", Journal of Central South University, 23(10), pp. 2720-2727, 2016.

https://doi.org/10.1007/s11771-016-3333-4

[28] Galushchak, I. V., Gorbatenko, V. Y., Shevelev, A. A. "A method for numerically simulating the thermal state of a tube with punched helical-tape finning", Thermal Engineering, 58(5), Article Number: 435, 2011.

https://doi.org/10.1134/S0040601511050065

[29] Ghachem, K., Hassen, W., Maatki, C., Kolsi, L., Al-Rashed, A. A. A. A., Borjini, M. N. "Numerical simulation of 3D natural convection and entropy generation in a cubic cavity equipped with an adiabatic baffle", International Journal of Heat and Technology, 36(3), pp. 1047-1054, 2018.

https://doi.org/10.18280/ijht.360335

[30] Al-Rashed, A. A. A. A., Aich, W., Kolsi, L., Mahian, O., Hussein, A. K., Borjini, M. N. "Effects of Movable-Baffle on Heat Transfer and Entropy Generation in a Cavity Saturated by CNT Suspensions: Three-Dimensional Modeling", Entropy, 19(5), Article Number: 200, 2017.

https://doi.org/10.3390/e19050200

[31] Al-Rashed, A. A. A. A., Kolsi, L., Tashkandi, M. A., Hasani Malekshah, E., Chamkha, A. J., Borjini, M. N. "Three-dimensional combined radiation-magnetoconvection of low electrically conductive dielectric oxide melt", International Journal of Numerical Methods for Heat \& Fluid Flow, 29(10), pp. 3611-3637, 2019. https://doi.org/10.1108/HFF-06-2018-0263

[32] Ghalambaz, M., Zhang, J. "Conjugate solid-liquid phase change heat transfer in heatsink filled with phase change material-metal foam", International Journal of Heat and Mass Transfer, 146, Article Number: 118832, 2020.

https://doi.org/10.1016/j.ijheatmasstransfer.2019.118832

[33] Ghalambaz, M., Mehryan, S. A. M., Hajjar, A., Veisimoradi, A. "Unsteady natural convection flow of a suspension comprising Nano-Encapsulated Phase Change Materials (NEPCMs) in a porous medium", Advanced Powder Technology, 31(3), pp. 954-966, 2020. https://doi.org/10.1016/j.apt.2019.12.010

[34] Ghalambaz, M., Zadeh, S. M. H., Mehryan, S. A. M., Pop, I., Wen, D. "Analysis of melting behavior of PCMs in a cavity subject to a non-uniform magnetic field using a moving grid technique", Applied Mathematical Modelling, 77, pp. 1936-1953, 2020. https://doi.org/10.1016/j.apm.2019.09.015 
[35] Ghalambaz, M., Groşan, T., Pop, I. "Mixed convection boundary layer flow and heat transfer over a vertical plate embedded in a porous medium filled with a suspension of nano-encapsulated phase change materials", Journal of Molecular Liquids, 293, Article Number: 111432, 2019. https://doi.org/10.1016/j.molliq.2019.111432

[36] Fodor, A. "Calculation of the temperature of boundary layer beside wall with time-dependent heat transfer coefficient", Periodica Polytechnica Mechanical Engineering, 54(1), pp. 15-20, 2010. https://doi.org/10.3311/pp.me.2010-1.03

[37] Mehryan, S. A. M., Vaezi, M., Sheremet, M., Ghalambaz, M. "Melting heat transfer of power-law non-Newtonian phase change nano-enhanced n-octadecane-mesoporous silica $\left(\mathrm{MPSiO}_{2}\right)$ ", International Journal of Heat and Mass Transfer, 151, Article Number: 119385, 2020.

https://doi.org/10.1016/j.ijheatmasstransfer.2020.119385

[38] Mehryan, S. A. M., Ghalambaz, M., Feeoj, R. K., Hajjar, A., Izadi, M. "Free convection in a trapezoidal enclosure divided by a flexible partition", International Journal of Heat and Mass Transfer, 149, Article Number: 119186, 2020. https://doi.org/10.1016/j.ijheatmasstransfer.2019.119186

[39] Kolsi, L. "Numerical Study of Natural Convection and Entropy Generation of $\mathrm{Al}_{2} \mathrm{O}_{3}$-Water Nanofluid within a Cavity Equipped with a Conductive Baffle", Journal of Applied Fluid Mechanics, 9(5), pp. 2177-2186, 2016.

https://doi.org/10.18869/acadpub.jafm.68.236.25506

[40] Kolsi, L., Abu-Hamdeh, N., Öztop, H. F., Alghamdi, A., Borjini, M. N., Ben Assia, H. "Natural convection and entropy generation in a three dimensional volumetrically heated and partially divided cavity", International Journal of Numerical Methods for Heat \& Fluid Flow, 26(8), pp. 2492-2508, 2016. https://doi.org/10.1108/HFF-09-2015-0358

[41] Kolsi, L., Hussein, A. K., Borjini, M. N., Mohammed, H. A., Aïssia, H. B. "Computational Analysis of Three-Dimensional Unsteady Natural Convection and Entropy Generation in a Cubical Enclosure Filled with Water- $\mathrm{Al}_{2} \mathrm{O}_{3}$ Nanofluid", Arabian Journal for Science and Engineering, 39(11), pp. 7483-7493, 2014. https://doi.org/10.1007/s13369-014-1341-y

[42] Rábai, G., Vad, J. "Aerodynamic study on straight, arc-swept and twisted stationary linear cascade blades", Periodica Polytechnica Mechanical Engineering, 53(1), pp. 33-40, 2009. https://doi.org/10.3311/pp.me.2009-1.05

[43] Hajjar, A., Mehryan, S. A. M., Ghalambaz, M. "Time periodic natural convection heat transfer in a nano-encapsulated phase-change suspension", International Journal of Mechanical Sciences, 166, Article Number: 105243, 2020. https://doi.org/10.1016/j.ijmecsci.2019.105243

[44] Rahimi, A., Kasaeipoor, A., Hasani Malekshah, E., Kolsi, L. "Lattice Boltzmann simulation of free convection in nanofluid filled cavity with partially active walls - entropy generation and heat line visualization", International Journal of Numerical Methods for Heat \& Fluid Flow, 28(10), pp. 2254-2283, 2018. https://doi.org/10.1108/HFF-06-2017-0229
[45] Rashidi, I., Kolsi, L., Ahmadi, G., Mahian, O., Wongwises, S., Abu-Nada, E. "Three-dimensional modelling of natural convection and entropy generation in a vertical cylinder under heterogeneous heat flux using nanofluids", International Journal of Numerical Methods for Heat \& Fluid Flow, 30(1), pp. 119-142, 2019. https://doi.org/10.1108/HFF-12-2018-0731

[46] Hegedűs, F., Rákos, R., Kullmann, L. "Experimental and numerical study on cavitating vortex shedding behind a square cylinder", Periodica Polytechnica Mechanical Engineering, 53(2), pp. 55-60, 2009.

https://doi.org/10.3311/pp.me.2009-2.01

[47] Almeshaal, M. A., Kalidasan, K., Askri, F., Velkennedy, R., Alsagri, A. S., Kolsi, L. "Three-dimensional analysis on natural convection inside a T-shaped cavity with water-based CNTaluminum oxide hybrid nanofluid", Journal of Thermal Analysis and Calorimetry, 139(3), pp. 2089-2098, 2020. https://doi.org/10.1007/s10973-019-08533-w

[48] Hnaien, N., Marzouk, S., Kolsi, L., Alsagri, A. S., Aissia, H. B., Jay, J. "Offset jet ejection angle effect in combined wall and offset jets flow: numerical investigation and engineering correlations", Journal of the Brazilian Society of Mechanical Sciences and Engineering, 41(11), Article Number: 479, 2019. https://doi.org/10.1007/s40430-019-1982-6

[49] Füle, P., Hernádi, Z. "Investigation of turbulent channel flow using local mesh refinement", Periodica Polytechnica Mechanical Engineering, 58(1), pp. 7-13, 2014. https://doi.org/10.3311/PPme.7182

[50] Goda, R., Bánhidi, L. "Investigation of average air velocity and turbulence intensity in a slot ventilated space", Periodica Polytechnica Mechanical Engineering, 58(2), pp. 77-81, 2014. https://doi.org/10.3311/PPme.7264

[51] Bidar, B., Shahraki, F., Mohebbi Kalhori, D. "3D Numerical Modelling of Convective Heat Transfer through Two-sided Vertical Channel Symmetrically Filled with Metal Foams", Periodica Polytechnica Mechanical Engineering, 60(4), pp. 193-202, 2016. https://doi.org/10.3311/PPme.8511

[52] Noghrehabadi, A., Behseresht, A., Ghalambaz, M., Behseresht, J. "Natural-Convection Flow of Nanofluids Over Vertical Cone Embedded in Non-Darcy Porous Media", Journal of Thermophysics and Heat Transfer, 27(2), pp. 334-341, 2013.

https://doi.org/10.2514/1.T3965

[53] Noghrehabadi, A., Pourrajab, R., Ghalambaz, M. "Effect of partial slip boundary condition on the flow and heat transfer of nanofluids past stretching sheet prescribed constant wall temperature", International Journal of Thermal Sciences, 54, pp. 253-261, 2012. https://doi.org/10.1016/j.ijthermalsci.2011.11.017

[54] Noghrehabadi, A., Pourrajab, R., Ghalambaz, M. "Flow and heat transfer of nanofluids over stretching sheet taking into account partial slip and thermal convective boundary conditions", Heat and Mass Transfer, 49(9), pp. 1357-1366, 2013. https://oi.org/10.1007/s00231-013-1179-y 
[55] Khrabry, A., Smirnov, E., Zaytsev, D., Goryachev, V. "Numerical Study of 2D and 3D Separation Phenomena in the Dam-Break Flow Interacting with a Triangular Obstacle", Periodica Polytechnica Mechanical Engineering, 60(3), pp. 159-166, 2016.

https://doi.org/10.3311/PPme.8948

[56] Fenyvesi, B., Horváth, Cs. "Investigation on the Nonconstant Behavior of a Vortex Flow Meter with Narrow Gauge Pipe via Conducting Measurements and Numerical Simulations", Periodica Polytechnica Mechanical Engineering, 61(3), pp. 247-254, 2017. https://doi.org/10.3311/PPme.10816

[57] Zadeh, S. M. H., Mehryan, S. A. M., Izadpanahi, E., Ghalambaz, M. "Impacts of the flexibility of a thin heater plate on the natural convection heat transfer", International Journal of Thermal Sciences, 145, Article Number: 106001, 2019.

https://doi.org/10.1016/j.ijthermalsci.2019.106001

[58] Jamesahar, E., Sabour, M., Shahabadi, M., Mehryan, S. A. M., Ghalambaz, M. "Mixed convection heat transfer by nanofluids in a cavity with two oscillating flexible fins: A fluid-structure interaction approach", Applied Mathematical Modelling, 82, pp. 72-90, 2020. https://doi.org/10.1016/j.apm.2019.12.018

[59] Rashad, A. M. "Natural convection boundary layer flow along a sphere embedded in a porous medium filled with a nanofluid", Latin American Applied Research, 44(2), pp. 149-157, 2014.

[60] Rashad, A. M. "Impact of anisotropic slip on transient three dimensional MHD flow of ferrofluid over an inclined radiate stretching surface", Journal of the Egyptian Mathematical Society, 25(2), pp. $230-237,2017$.

https://doi.org/10.1016/j.joems.2016.12.001

[61] Rashad, A. M. "Unsteady nanofluid flow over an inclined stretching surface with convective boundary condition and anisotropic slip impact", International Journal of Heat and Technology, 35(1), pp. 82-90, 2017.

https://doi.org/10.18280/ijht.350111

[62] Rashad, A. M. "Effects of radiation and variable viscosity on unsteady MHD flow of a rotating fluid from stretching surface in porous medium", Journal of the Egyptian Mathematical Society, 22(1), pp. 134-142, 2014.

https://doi.org/10.1016/j.joems.2013.05.008

[63] Rashad, A. M. "Impact of thermal radiation on MHD slip flow of a ferrofluid over a non-isothermal wedge", Journal of Magnetism and Magnetic Materials, 422, pp. 25-31, 2017.

https://doi.org/10.1016/j.jmmm.2016.08.056

[64] Ismael, M. A. "Numerical solution of mixed convection in a lid-driven cavity with arc-shaped moving wall", Engineering Computations, 34(3), pp. 869-891, 2017. https://doi.org/10.1108/EC-11-2015-0368

[65] Ismael, M. A. "Forced convection in partially compliant channel with two alternated baffles", International Journal of Heat and Mass Transfer, 142, Article Number: 118455, 2019. https://doi.org/10.1016/j.ijheatmasstransfer.2019.118455
[66] Ismael, M. A. "Double-Diffusive Mixed Convection in a Composite Porous Enclosure with Arc-Shaped Moving Wall: Tortuosity Effect", Journal of Porous Media, 21(4), pp. 343-362, 2018. https://doi.org/10.1615/JPorMedia.v21.i4.40

[67] Ismael, M. A. "Natural convection in a wavy porous enclosure heated by an internal circular cylinder", Al-Qadisiyah Journal for Engineering Sciences, 4(3), pp. 204-220, 2011.

[68] Ismael, M. A., Al-Rabeh, R. H. "A new measuring criterion of the performance of the electromagnetic flow meter", Basrah Journal for Engineering Science, 10(1), pp. 133-144, 2010.

[69] Selimefendigil, F. "Numerical investigation and recurrence plot analysis of pulsating magnetohydrodynamic mixed convection over a backward facing step", Nonlinear Analysis, 20(3), pp. 428-446, 2015.

https://doi.org/10.15388/NA.2015.3.8

[70] Selimefendigil, F. "Mixed convection in a lid-driven cavity filled with single and multiple-walled carbon nanotubes nanofluid having an inner elliptic obstacle", Propulsion and Power Research, 8(2), pp. 128-137, 2019. https://doi.org/10.1016/j.jppr.2019.01.007

[71] Selimefendigil, F. "Natural Convection in a Trapezoidal Cavity with an Inner Conductive Object of Different Shapes and Filled with Nanofluids of Different Nanoparticle Shapes", Iranian Journal of Science and Technology, Transactions of Mechanical Engineering, 42(2), pp. 169-184, 2018.

https://doi.org/10.1007/s40997-017-0083-3

[72] Selimefendigil, F. "Numerical Investigation and POD-Based Interpolation of Natural Convection Cooling of Two Heating Blocks in a Square Cavity", Arabian Journal for Science and Engineering, 39(3), pp. 2235-2250, 2014. https://doi.org/10.1007/s13369-013-0814-8

[73] Menni, Y., Chamkha, A. J., Makinde, O. D. "Turbulent Heat Transfer Characteristics of a W-Baffled Channel Flow - Heat Transfer Aspect", Defect and Diffusion Forum, 401, pp. 117-130, 2020. https://doi.org/10.4028/www.scientific.net/DDF.401.117

[74] Demartini, L. C., Vielmo, H. A., Möller, S. V. "Numeric and experimental analysis of the turbulent flow through a channel with baffle plates", Journal of the Brazilian Society of Mechanical Sciences and Engineering, 26(2), pp. 153-159, 2004. https://doi.org/10.1590/S1678-58782004000200006

[75] Launder, B. E., Spalding, D. B. "The numerical computation of turbulent flows", Computer Methods in Applied Mechanics and Engineering, 3(2), pp. 269-289, 1974. https://doi.org/10.1016/0045-7825(74)90029-2

[76] Patankar, S. V. "Numerical heat transfer and fluid flow", McGrawHill, New York, NY, USA, 1980.

[77] ANSYS Inc. "ANSYS Fluent 12.0, Theory Guide", ANSYS Inc., Canonburg, PA, USA, 2012. 